\title{
Translanguaging and linguistic landscapes: A study of Manitoban schoolscapes
}

\author{
Gail Cormier \\ gcormier@ustboniface.ca \\ UNIVERSITÉ DE SAINT-BONIFACE
}

\begin{abstract}
The purpose of this article will be to review how the theory of translanguaging can be used to explore the linguistic landscapes of bi- and multilingual schools. Such an approach requires researchers to view space and language holistically since translanguaging practices occur not only within an individual but also within a particular space. As a result, a school's linguistic landscape (schoolscape) can be viewed as a representation of the students' language repertoire. Qualitative data will be presented from three different secondary school contexts in Manitoba, Canada; French immersion single-track, French immersion dual-track and French-language schools. This data will illustrate how translanguaging offers a new way to approach the analysis of schoolscapes in bi- and multilingual contexts.
\end{abstract}

Key words: translanguaging, linguistic landscapes, French immersion education, French-language education

\section{Résumé}

Cet article cherche à présenter la façon dont la théorie de translanguaging peut être employée pour analyser le paysage linguistique d'écoles bilingues et plurilingues. En utilisant le translanguaging en tant que cadre théorique, les chercheurs voient la langue et l'espace de manière holistique puisqu'il s'agit des pratiquent linguistiques non seulement au sein d'un individu mais aussi au sein d'un contexte particulier. Ainsi, le paysage linguistique devient alors une représentation du repertoire langagier des élèves. Des données qualitatives provenant de trois contextes scolaires différents : l'immersion à simple voie, l'immersion à double voie et francophone en milieu minoritaire seront présentées afin d'illustrer la manière dont la théorie de translanguaging peut être employée dans la recherche portant sur les paysages linguistiques scolaires en milieu bi- ou plurilingue.

Mots-clés: translanguaging, paysage linguistique, éducation en immersion française, éducation en milieu minoritaire francophone 


\section{Introduction}

The term "translanguaging" originated in the classroom and as a pedagogical technique (Williams, 1996). Today, it is a theory that focuses on individuals and their specific linguistic practises that can be applied to a variety of different research contexts. Similarly, linguistic landscape research began as an analysis of "visible written language" in public spaces (Gorter, 2013). Currently, linguistic landscape research has occurred worldwide and evolved to focus on a variety of different semi-public spaces, such as schools. This article ${ }^{1}$ aims to apply the theory of translanguaging to the study of linguistic landscapes, in particular scholastic linguistic landscapes (schoolscapes) (Brown, 2012). In doing so, importance is attributed not only to individual linguistic practices but also to the contexts in which those practices occur. First, it will be important to understand the theoretical framework that meshes translanguaging and linguistic landscapes. Next, the Manitoban context as well as the differences between three school contexts where French is the language of instruction will be explored. Finally, a selection of qualitative data from different Manitoban schools will serve to exemplify how translanguaging can be used effectively as a theoretical framework to analyze schoolscapes.

\section{Theoretical framework}

\section{Linguistic landscapes and schoolscapes}

Linguistic landscapes are essentially public spaces that contain written language. In 1997, Landry and Bourhis were the first to study linguistic landscapes while looking at the ethnolinguistic vitality of French in Canada. For Landry and Bourhis (1997), it was important to measure how present French was in public spaces. Since then, worldwide, many researchers have chosen to conduct linguistic landscape studies that focus on the interaction between minority and majority languages in public spaces (Blackwood, 2011; Cenoz \& Gorter, 2006; Curtin, 2008; Edelman, 2014). Other Canadian studies tend to focus on the relationship between English and French in minority and majority settings (Cormier, 2015; Gade, 2003; Gilbert, 2010; Lamarre, 2014). A common finding in the aforementioned studies was that the minority language was underrepresented even in territories where it was widely spoken by the population. Particularly, it is felt that when a minority language is present in a public space it is symbolic of that language's status in society (Biró, 2016).

Over time, linguistic landscape studies have sought to make connections between the language in public spaces and for example, the economy (Cenoz \&

\footnotetext{
${ }^{1}$ This work was supported by the Social Sciences and Humanities Research Council of Canada under the Joseph-Armand-Bombardier Canada Graduate Scholarship award 767-2014-1468.
} 
Gorter, 2008), language policies (Shohamy, 2012), identity (Ben-Rafael, 2008; Curtin, 2008; Dagenais, Moore, Sabatier, Lamarre, \& Armand, 2008) and language attitudes or ideologies (Dailey, Giles, \& Jansma, 2005; Plessis, 2011). Currently, linguistic landscape studies have a large scope of related topics. Gorter (2013) outlines the importance of linguistic landscape research:

The linguistic landscape of a specific area marks the geographical space inhabited by a language group or groups. It indexes a sociolinguistic reality that touches on the relationships between people living in this specific area and beyond. The linguistic landscape not only reflects the status of different languages in society, but it also acts as a force shaping how languages are being perceived and used by the population. (p. 199)

Linguistic landscapes are not simply a collection of signs and images. It is clear that these images shed light on greater issues related to language and language use. Although linguistic landscape researchers have generally focused on the analysis of public spaces, a new sub-division of researchers have started to look at semi-public spaces as well, such as schools (Amara, 2018; Biró, 2016; Brown, 2012; Dressler, 2015; Gorter, 2018). These studies on scholastic linguistic landscapes are known as schoolscapes, a term coined by Brown (2012).

One body of linguistic landscape research in schools focuses on its pedagogical utility for language learning or language awareness (Burwell \& Lenters, 2015; Dagenais et al., 2008; Hewitt-Bradshaw, 2014; Rowland, 2013; Sayer, 2010). In these studies, linguistic landscape images from the outside community are analyzed in class. In some cases, the students are required to take pictures and bring them to class while in other cases the teacher uses images he or she took. However, these studies do not analyze the linguistic landscape within the schools these students attend.

Another body of research, called "schoolscapes", focuses on the linguistic landscape within schools. For example, Dressler (2015) studied the linguistic landscape of a dual-track German-English school in Alberta, Canada. The findings pointed to the prevalence of the majority language (English) and a lower status afforded to the minority language (German) within the schoolscape. Moreover, Brown (2012) studied the linguistic landscape of three Vorro-language elementary schools in Estonia in order to uncover the language ideologies that were symbolically present in the schoolscape. More recent studies have also looked at language ideologies and the hidden curriculum in schoolscapes but have employed a 'tourist guide technique' wherein teachers or principals are interviewed while the researcher takes pictures of the schoolscape (Amara, 2018; Biró, 2016; Przymus \& Kohler, 2018; Szabó, 2015). These more recent studies generally analyze more than one school and tend to use both elementary and secondary schools as research sites. However, 
no schoolscape study to date has analyzed students' perceptions of their own or other schoolscapes. Moreover, applying the concept of translanguaging to linguistic landscape research is a new approach (Gorter \& Cenoz, 2015; Pennycook, 2017). The following section will start by defining translanguaging and then the connections between translanguaging and linguistic landscapes will be drawn.

\section{Translanguaging}

In the beginning, the term translanguaging referred to the use of what linguists call code-switching as a pedagogical tool in language classrooms (Williams, 1996). While there is still some debate with regards to the use of the term code-switching, it is generally agreed upon that translanguaging goes beyond code-switching and has evolved into a theoretical stance (Poza, 2017). This stance views languages as inextricably connected and not part of separate, autonomous systems or codes. The different languages bi- and multilinguals can speak are not separated within the mind but instead part of one "integrated system" or repertoire (Canagarajah, 2011, p. 401). In order to communicate effectively and to understand others, individuals who speak more than one language can access different parts of their linguistic repertoire (Pacheco \& Smith, 2015). This means that they may mix socially named languages or borrow elements from different languages in order to communicate. Translanguaging acknowledges this type of communication as not only acceptable but natural. Essentially, translanguaging theorists look at language and languages holistically rather than separating them into groups.

In fact, the linguistic practices of bilinguals and multilinguals are of particular interest to translanguaging theorists. Such multilingual practices are "naturally occurring" (Canagarajah, 2011, p. 401) and demonstrate great flexibility across languages in communication (Velasco \& García, 2014). In most contexts, the ultimate goal is effective communication. Translanguaging recognizes that effective communication comes in different forms and can use more than one language. Such a view accepts many different linguistic features as translanguaging; such as translation, what linguists refer to as code-switching (Pacheco \& Smith, 2015) and codemeshing, which concentrates on language alternation in writing (Canagarajah, 2011). Translanguaging practices also include the "multiple and dynamic varieties of these different languages - vernacular, formal, academic, as well as those based on race, ethnicity, affinity, or affiliation" (Hornberger \& Link, 2012, p. 242). Not only are different language types viewed holistically but also linguistic practices allowing the practices of all levels of bilinguals and multilinguals to be viewed as appropriate if they result in effective communication (Allard, 2017). In this sense, translanguaging can even be used to analyze the linguistic practices of monolinguals since 
their linguistic repertoires also contain formal and informal language, vernacular, a particular accent and vocabulary borrowed from other languages as well. Therefore, translanguaging focuses on a variety of linguistic features and views them as connected.

While translanguaging shares the idea of the interconnectedness of languages with other theorists (Bakhtin, 1981), it pushes beyond acknowledging that languages are connected and attempts to dissolve the figurative borders between languages (Otheguy, 2016). When languages are separated it results in ideologies that can be harmful to language learning. For example, it encourages the belief that in order to count as a bilingual, one must speak both languages as a native, monolingual speaker. Translanguaging rejects the idea that bilingualism is "merely monolingualism times two" (Sayer, 2013, p. 85) and the idea that bilingualism is simply a transitionary phase towards monolingualism (MacSwan, 2017). Instead, translanguaging views bilingualism as the result of language interaction. In sum, adhering to a single, complex language repertoire and rejecting the notion of separate languages is "most useful when we want to loosen the grip of social categories and describe the speakers' idiolects and the actual linguistic behaviors, their language practices" (Otheguy, García, \& Reid, 2015, p. 298). In this way, translanguaging valorizes bilinguals and their linguistic practices.

Translanguaging also accounts for the influence of context or space on linguistic practices. This is realistic since the context greatly impacts the language choices bilinguals and multilinguals will make. For example, if the use of a language a student speaks is not permitted in the classroom he or she will likely "inhibit the deployment of part of their unitary competence, doing so artificially, for the sake of social rules" (Otheguy, 2016, p. xi). In that sense, "language is never separate from contexts of use", and it is equally important to understand the context surrounding linguistic practices (Smith, Pacheco, \& de Almeida, 2017, p. 8). Pennycook (2017) agrees and locates the notion of spatial repertoires within the translanguaging paradigm by stating that "material surrounds are understood not only as a context but rather as part of an interactive whole that includes people, objects and space" (p. 278). In summary, using translanguaging as a theoretical framework requires researchers to view various languages and various linguistic practices as belonging to a single repertoire. Ultimately, that linguistic repertoire is also influenced by the speakers and the space they occupy.

\section{Translanguaging and linguistic landscapes}

Linguistic landscape researchers focus on the analysis of space. Translanguaging is a useful theoretical framework to adopt when analyzing linguistic landscapes because signs can influence translanguaging practices (Pennycook \& 
Otsuji, 2014). For example, the presence of a minority language on a sign may encourage individuals to use that language or request services in that language. In the same way, local translanguaging practices have the power to "shape the linguistic landscapes" of places (p. 168). For instance, if store owners who speak a minority language decide that it is important to advertise in that language, they are sending the message to the public that their language is worth using (Gilbert, 2010). As a result, identity, language and space go hand in hand. Thus, how a space is defined is dependent on the interaction between the people that occupy that space, its signs and the translanguaging practices that occur in that space. It is then not surprising that linguistic landscape researchers are starting to include translanguaging theories into their work as it allows for a more holistic view of language and space (Gorter \& Cenoz, 2015).

In the same way that translanguaging researchers push beyond the boundaries of named languages, so do linguistic landscape researchers. They push beyond "the boundaries of individual signs and languages" (Gorter \& Cenoz, 2015, p. 54) in order to draw the connection between language and space. Adopting a translanguaging framework to study linguistic landscapes requires researchers to understand the space in which signs are located on a deeper level. Along with the signs, the individuals who interact with those signs make up the spatial repertoire of a particular space. The notion of spatial repertoires is then useful in linking translanguaging to linguistic landscapes since its premise lies in the notion that contexts should be viewed holistically (Pennycook, 2017). Essentially, this expands the analysis of space to spatial repertoires, which is akin to expanding the analysis of language to linguistic repertoires.

Since translanguaging researchers place an importance on speakers and their translanguaging practices, so should linguistic landscape researchers. It is important to take a closer look at the individuals who live in the space being analyzed. Linguistic landscape researchers can accomplish this by interviewing the individuals who created signs or those who live in the area and who interact with the signs of a particular space (Pennycook, 2017). In doing so, they may wish to explore elements linked to linguistic repertoires such as linguistic identity and translanguaging practices such as code-switching, accents and vernacular. In the end, a linguistic landscape study that uses translanguaging as a theoretical framework should recognize that translanguaging practices are diverse, dynamic, naturally occurring, linked to spatial repertoires and should be viewed positively.

However, when it comes to educational contexts, language interaction is not often viewed in this way. Schools often promote a monolingual ideology that seeks to keep languages separate and to promote standard language varieties. The monolingual ideology is defined as an elevated status 
and value attributed to the dominant language (Blackledge, 2001). Agirdag (2010) agrees, stating that the monolingual ideology is then "imposed on the dominated groups via the school system" (p. 311). Schools generally focus on the instruction of the dominant language, and its standard form. As such, all other subjects are taught through the medium of that language. The monolingual ideology of the United States is evident when it is commonly believed that "English-only" programs promote patriotism and adherence to the nation's dominant language (Gershon \& Pantoja, 2011). Nevertheless, other educational programs exist, such as dual-language schools in the United States and French immersion schools in Canada. Since these schools elevate the status of minority languages by using them as languages of instruction, they are thought to promote bilingualism. While one might assume that these schools elevate the status of minority languages, schoolscape studies have found that the dominant language is afforded a greater symbolic importance within the school (Brown, 2012; Dressler, 2015; Szabó, 2015). Since linguistic landscape studies analyze space, it will be important to describe and locate this study's spatial repertoire.

\section{Context}

Manitoba is one of Canada's Western provinces. English is the language of the majority and one of Canada's official languages. French, the other official language, is spoken as a first language by $3.9 \%$ of the Manitoban population (Canada, 2013). While Manitoba is not an officially bilingual province, many schools within the province use French as a language of instruction. Basic French classes (currently known as French Culture and Communication) are typically given to all students from Grades 4 to 9 in schools where English is the language of instruction. It is recommended that $13 \%$ of the school day in Grade 7 and 8 be allotted for French instruction (Manitoba, 2017). However, other programs, which offer more extensive French instruction, are also offered within the province in the form of the French-language program and the French immersion program.

\section{French-language education}

French-language schools in Manitoba are for a specific population. These schools exist due to the Canadian Charter of Rights and Freedoms, which guarantees education in French for Francophones living outside of Québec. In order to attend a French-language school, you must be a "right-holder" (Landry \& Forgues, 2007, p. 5). Right-holders are individuals who can claim francophone heritage. This heritage then gives them the right to French-minority education for themselves and for their children. While they may be able to claim Francophone heritage, this does not necessarily mean that upon starting school in 
kindergarten the students are competent in French or that it is their first language (Pilote \& Magnan, 2008).

One of the main goals of French-language schools is to promote French for "cultural survival and the ethnolinguistic vitality of the group" (Landry \& Forgues, 2007, p. 6). Attaining this goal is increasingly challenging due to the local context in Manitoba where English is the language of the majority. Nevertheless, French-language schools play an important role in language maintenance. For some students, the school is the only place where French is used as a language of communication. In order to maintain the French language, all subjects are taught in French and French-language schools do not present English instruction until Grade 4. This ensures "that the minority language is maintained and fostered, given that the majority language is usually dominant in most other social and institutional domains" (May, 2012, p. 187). Although all subjects are taught in French, students who graduate from French-language schools are expected to be "highly functioning bilinguals with a strong Francophone identity" (Cormier, Bourque, \& Jolicoeur, 2014, p. 161). Bilingualism, in the case of French-language students, is more a result of the minority context than of programming.

\section{French immersion education}

Canada is well known for having initiated the French immersion program. It is a bilingual program that was designed for children who speak English or a language other than French as their first language. The program was first piloted in Saint-Lambert, Québec in 1965 (Genesee, 2008). Since then, its popularity has grown and French immersion programs are offered in all the Canadian provinces with an overall enrollment rate of more than 375,000 students (Allison, 2015, p. 289).

The main objectives of the French immersion program are "high proficiency in English, functional fluency in French, and mastery of the required skills and abilities in all other subjects" (Goldberg \& Noels, 2006, p. 429). The program strives to meet these goals by 'immersing' the students in the French language. Students are strongly encouraged to address their teachers and fellow students in French as well as all core subjects are taught in French (Makropoulos, 2010). However, the French immersion program does not share the goal of language maintenance with French-language schools since their raison d'être is to add French to an already existing other language instead of to maintain French. Nevertheless, the increased exposure and use of French in the French immersion program is said to develop fluent French speakers (Baker \& MacIntyre, 2003; Saindon, Landry, \& Boutouchent, 2011). At the same time: 
A common finding from L2 immersion programs across a variety of contexts is that students gain a reasonable level of fluency and literacy in L2 at no apparent cost to their academic skills in the socially dominant language. (Cummins, 2014, p. 3)

French immersion students then become fluent in French while also maintaining their first language(s).

While most French immersion programs offer instruction in French for the majority of the school day (Swain \& Lapkin, 1977/2008), the format in which the program is offered can differ from school to school and district to district. Children can start French immersion at different grade levels - early (kindergarten or Grade 1), mid (Grade 4), or late immersion (Grade 6 or 7) (Makropoulos, 2010). In Manitoba, French immersion schools generally follow the early model. In those schools, English Language Arts instruction begins in Grade 1 (Ewart \& Straw, 2001). All French immersion programs are offered in either their own schools (single-track) or within English-language schools (dual-track). While the goals of the program remain the same in singleand dual-track schools, the school contexts differ which tends to result in some differences between the programs.

Since single-track programs have their own schools, they can exercise more control over language use outside of the classroom. Single-track French immersion schools make an effort to hire staff and teachers who are fluent in French which allows for French language use in school activities and day-today interactions (Hermanto, Moreno, \& Bialystok, 2012). Moreover, optional courses and extracurricular activities are often offered in French in single-track schools. In dual-track schools, the space within the school is shared with the other regular English-program students. In some cases, the immersion program classrooms are "located in a separate wing" (Dressler, 2015, p. 132). While French immersion students "are encouraged to speak French everywhere in the school" (Roy, 2010, p. 551), realistically, this is virtually impossible to do in the dual-track setting when other staff and students do not speak French. While it seems logical that the single-track environment offers more exposure to French, dual-track French immersion programs remain popular in Manitoba, especially in rural locations and at the secondary level. The main difference between French immersion single-track and dual-track schools comes down to a question of space, which is the main topic of analysis for linguistic landscape researchers.

\section{Methods}

Considering these different education programs, this article reports on a selection of data collected from three high schools in Manitoba where French was the language of instruction. The three study sites, a French-language high 
school, a French immersion single-track high school and a French immersion dual-track high school, were selected since they differed in terms of educational contexts but were similar in terms of their educational goal (instruction of the French language). In spring 2016, photographs of each schoolscape were taken for a total of corpus of 336 permanent and non-permanent signs. It is important to note that all signs were visible to the average visitor and were all located in the hallways of the schools. While collecting these photographs, an initial selection was made. For example, elements such as Exit signs were only taken once even though the same sign appeared in several places in the school. As well, some schools had quotation posters placed throughout the school. I took pictures of some but not all of those posters. As well, 37 Grade 11 students (aged 15 to 17 years old) from the three high schools participated in a semi-structured interview and a photo-elicitation interview (Biag, 2014). During the photo-elicitation interviews, students were asked to analyze a selection of images from their own and the other schoolscapes studied and to guess from which school the signs came. Participants chose their own pseudonyms that will be given to reference quotations. For the purpose of this paper, three images from the corpus have been selected and will serve to illustrate how translanguaging can be a useful theory when analyzing linguistic landscape data.

\section{Results and discussion}

While instances of translanguaging were common in the interviews as well as in the corpus of linguistic landscape images, this paper will focus on three themes related to translanguaging. To begin, two types of translanguaging practices, that I will define as translation and codemeshing, will be explored. The final example will explore the notion of bilingual linguistic identity as seen through the signs.

\section{Translation}

Within all three school contexts, bilingual French/English signs were found. Both languages were used on these signs to communicate a message. While some might consider this practice as co-languaging (Allard, 2017), since the information is repeated more or less word-for-word, these bilingual signs will be considered as examples of translation. However, because both languages are being used and activated, this practice can be qualified as translanguaging. In fact, Gorter and Cenoz (2015) found that multilinguals do not ignore languages on signs just because information is repeated; they actually read all the languages and do not focus on just one. Therefore, creating and being exposed to multilingual or bilingual signage activates the students' complex language repertoire.

The use of both languages held symbolic importance for the students 


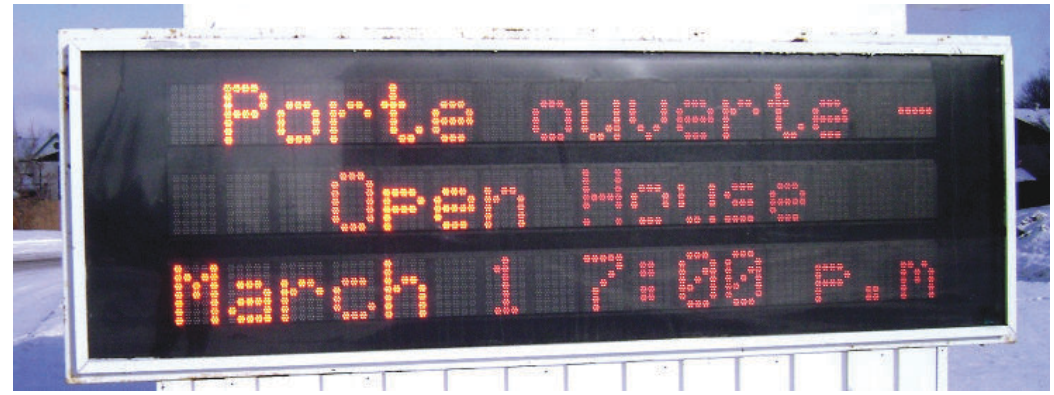

Figure 1

Example of translation

who participated in the photo-elicitation interviews. While they acknowledged that bilingual signs were not necessary for informational purposes, they felt they were inclusive. Bilingual signs included more individuals, since monolingual Anglophones and Francophones and French/English bilinguals could read them.

Figure 1 is an example of a bilingual sign. It was a digital message written on the outdoor sign of the single-track school. Many participants noted that French was placed first in this sign. In linguistic landscape research, when a language is placed first or on the left (for languages using the Roman alphabet), it is placed in a position of power because it will be read first (Backhaus, 2008). For the participants, the placement of French meant that the sign came from either a French-language school or a French immersion school who emphasized French. The presence and placement of French on this sign contradicts the monolingual ideology, since the minority language is placed in a more powerful position. However, both languages are separated by a dash indicating that the school views them as separate languages.

Although French comes first in Figure 1, only the name of the event is translated. The rest of the information is given only in English. Moreover, the expression "Open House" is plural in French and should read "Portes ouvertes". While none of the participants noticed this mistake, two Frenchlanguage participants (Blake and Elektra) unconsciously corrected it by referring to the event on the sign as 'les portes ouvertes'. This shows that signs have the power to activate existing linguistic repertoires, in this case a particular expression in French. Since translanguaging is used on the outdoor school sign, it sends the message that both languages are accepted at school, which in turn may influence translanguaging practices within the school. Moreover, using French on an outdoor sign may also be a way to promote the French immersion program in general since Przymus and Kohler (2018) discovered that 


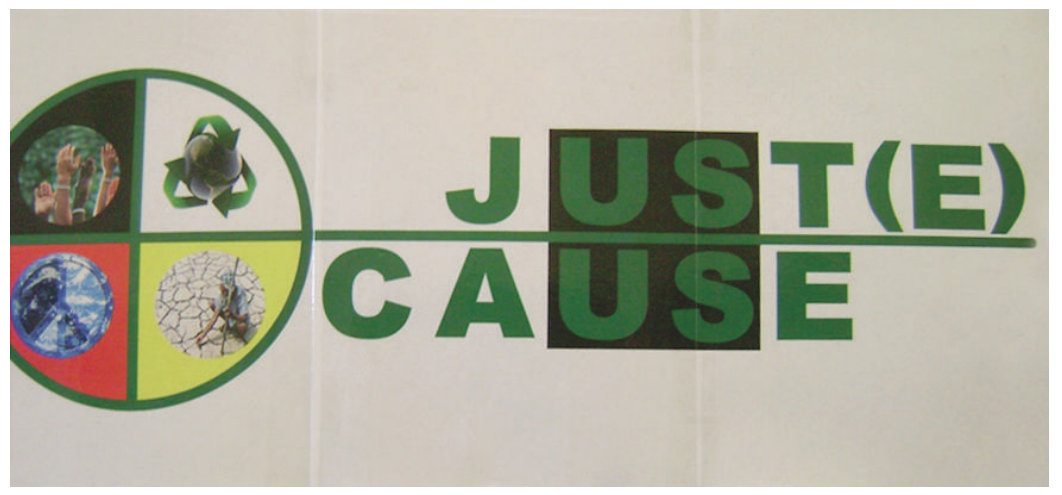

Figure 2

Example of codemeshing

the presence of Spanish on signs in monolingual English neighbourhoods in the United States encouraged parents to enroll their children in dual-language programs. It can be said this sign supports other schoolscape findings that found that dominant languages were afforded a position of power by the school (Brown, 2012; Dressler, 2015; Szabó, 2015). However, the mere presence of French, although unnecessary in this case for communication purposes, symbolizes that the school considers French and more importantly bilingualism to be important.

\section{Codemeshing}

The majority of the bilingual signs from the three schools repeated information in French or English. While this repetition is symbolic and offers a space for the minority language, it also teaches students to separate the languages in their repertoire. This is because both languages are being used to communicate the same information. The separation of languages in school is a common practice since teachers often feel responsible for presenting standard language forms and insisting that languages should be kept apart (Blackledge \& Creese, 2010; Jørgensen, 2012). It is then not surprising that all the bilingual signs except one avoided mixing languages. Figure 2 is an example of a sign found in the dual-track school that makes an attempt to mesh French and English.

Codemeshing is a translanguaging practice wherein there is an apparent alternation between two or more languages in writing (Canagarajah, 2011). Figure 2 activates both languages. By adding the letter "e" to the English word 'just' it becomes the French word "juste". Although the words "juste" and "cause" exist in French, the placement of the words is incorrect. In French, it should read "une cause juste" instead of "une juste cause". Nevertheless, in 
order to understand why the "e" is present on the sign, you have to have knowledge of French. In linguistic landscape studies, bilingual signs that play with words but can only be understood by bilinguals are called "bilingual winks" (Lamarre, 2014, p. 131). Although many students thought it was interesting that the sign worked in both languages, some noted that there was an emphasis on English since the word "us" was highlighted in black. It seems clear that, although an effort was made to include French on this sign, it had been written in English first.

\section{Bilingual linguistic identity}

All the participants were either bilingual or multilingual, and the majority chose to identify themselves as bilinguals. When trying to decide from which school the signs came, participants often associated the language of a sign with a particular school context. They predicted that French-only signs were from the French-language school, bilingual signs were from the French immersion single-track school and English-only signs were from the dual-track or an English school. Such an interpretation speaks to their evaluation of each school's identity. While in some instances this evaluation was accurate, all the schools had examples of English-only, French-only and bilingual signs.

A school's identity, as interpreted from its schoolscape, can in fact be very powerful. This was the case with two participants from the French-language school. They assumed all the signs in their school were either French-only or bilingual. Both Lina and Eveline identified specific sections of Figure 3 that they thought were written in French as well as English. In reality, the sign did not contain any French. With regard to translanguaging, clearly this Englishonly sign activated the participants' bilingual language repertoire. More importantly, because they felt French belonged in their schoolscape, they created a bilingual sign in their mind when it did not in fact exist. These examples illustrate that translanguaging practices occur in schools and that these practices are reflected in the school's space.

\section{Conclusion}

When translanguaging is applied to the study of linguistic landscapes, it allows for a focus on the micro. Translanguaging was shown to focus on the individual and on individual linguistic practices. In the same way, linguistic landscape research focuses on a specific context, on the spatial repertoire. Ultimately, linguistic practices do not occur in isolation; they occur naturally within the individual and within a particular space. Using translanguaging and linguistic landscapes together when studying a Manitoban schoolscape allowed for a description of linguistic practices in the context in which they occur. While one could argue that a schoolscape is simply a collection of words or languages, 


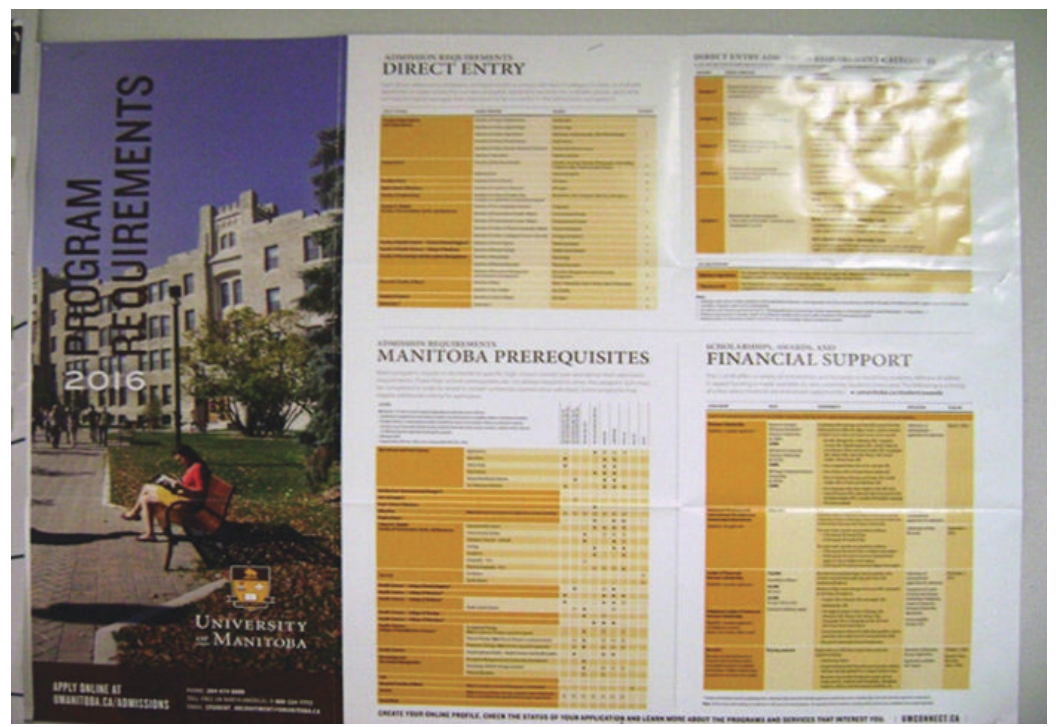

Figure 3

English-only sign

as linguistic landscape researchers know, words, languages and images symbolize much more and offer insight into macro relationships that occur inside and outside a particular space. It is precisely this concept that requires more research. Particularly, the link between linguistic landscapes, language ideologies and translanguaging would be important to explore.

As shown in the schoolscape examples in this study, dominant languages are favoured and languages are commonly separated at school. Adopting a translanguaging philosophy within a school supposes that these divisions between languages do not have to exist. In order to truly adhere to this philosophy, schools need to transform not only their pedagogical activities but also their space. If schools are to welcome translanguaging practices into their classrooms with the goal of acknowledging and promoting linguistic diversity (Allard, 2017; Canagarajah, 2011; García \& Kleyn, 2016; MacSwan, 2017; Pacheco \& Miller, 2016), they should also work to make this philosophy visible within the school.

\section{References}

Agirdag, O. (2010). Exploring bilingualism in a monolingual school system: Insights from Turkish and native students from Belgian schools. British Journal of Sociology of Education, 31, 307-321. doi.org/10.1080/01425691003700540 
Allard, E.C. (2017). Re-examining teacher translanguaging: An ecological perspective. Bilingual Research Journal, 40, 116-130. doi.org/10.1080/15235882.2017.1306597

Allison, D.J. (2015). School choice in Canada: Diversity along the wilddomesticated continuum. Journal of School Choice, 9, 282-309. doi.org/10.1080/15582159.2015.1029412

Amara, M.H. (2018). Palestinian schoolscapes in Israel. Asian-Pacific Journal of Second and Foreign Language Education, 3. doi.org/10.1186/s40862-018-0047-1

Backhaus, P. (2008). Rules and regulations in linguistic landscaping: A comparative perspective. In E. Shohamy \& D. Gorter (Eds.), Linguistic landscapes: Expanding the scenery (pp. 157-172). Florence, KY: Routledge.

Baker, S.C., \& MacIntyre, P.D. (2003). The role of gender and immersion in communication and second language orientations. Language Learning, 53(S1), 65-96. [Supplement] doi.org/10.1111/0023-8333.00224

Bakhtin, M.M. (1981). The dialogic imagination: Four essays. Austin: University of Texas Press.

Ben-Rafael, E. (2008). A sociological approach to the study of linguistic landscapes. In E. Shohamy \& D. Gorter (Eds.), Linguistic Landscapes: Expanding the scenery (pp. 40-54). Florence, KY: Routledge.

Biag, M. (2014). Perceived school safety: Visual narratives from the middle grades. Journal of School Violence, 13, 165-187. doi.org/10.1080/15388220.2013.831769

Biró, E. (2016). Learning schoolscapes in a minority setting. Acta Universitatis Sapientiae, Philologica, 8(2), 109-121. doi.org/10.1515/ausp-2016-0021

Blackledge, A. (2001). Literacy, schooling and ideology in a multilingual state. Curriculum Journal, 12, 291-312. doi.org/10.1080/09585170110089637

Blackledge, A., \& Creese, A. (2010). Multilingualism: A critical perspective. London: Continuum.

Blackwood, R.J. (2011). The linguistic landscape of Brittany and Corsica: A comparative study of the presence of France's regional languages in the public space. Journal of French Language Studies, 21(02), 111-130. doi.org/10.1017/S0959269510000281

Brown, K. (2012). The linguistic landscape of educational spaces: Language revitalization and schools in southeastern Estonia. In D. Gorter, H.F. Marten, L. Van Mensel, \& G. Hogan-Brun (Eds.), Minority languages in the linguistic landscape (pp. 281298). Basingstoke, UK: Palgrave Macmillan.

Burwell, C., \& Lenters, K. (2015). Word on the street: Investigating linguistic landscapes with urban Canadian youth. Pedagogies: An International Journal, 10, 201221. doi.org/10.1080/1554480X.2015.1029481

Canada. Treasury Board of Canada Secretariat (TBC). (2013). Linguistic minority populations by first official language spoken (2011 census data). 
www.canada.ca/en/treasury-board-secretariat/services/values-ethics/official-languages/ linguistic-minority-populations-first-official-language-spoken-2011-census-data. html

Canagarajah, S. (2011). Codemeshing in academic writing: Identifying teachable strategies of translanguaging. Modern Language Journal, 95, 401-417. doi.org/10.1111/j.1540-4781.2011.01207.x

Cenoz, J., \& Gorter, D. (2006). Linguistic landscape and minority languages. International Journal of Multilingualism, 3, 67-80. doi.org/10.1080/14790710608668386

Cenoz, J., \& Gorter, D. (2008). Language economy and linguistic landscape. In E. Shohamy \& D. Gorter (Eds.), Linguistic landscapes: Expanding the scenery (pp. 55-69). Florence, KY: Routledge.

Cormier, G. (2015). Le paysage linguistique en milieu minoritaire: une étude de l'affichage commercial à Saint-Boniface, au Manitoba. Minorités Linguistiques et Société, 5, 84-99.

Cormier, M., Bourque, J., \& Jolicoeur, M. (2014). (Re)-introduction to French: four education models to revitalise an endangered group in Eastern Canada. International Journal of Bilingual Education and Bilingualism, 17, 160-177. doi.org/10.1080/13670050.2013.866626

Cummins, J. (2014). To what extent are Canadian second language policies evidencebased? Reflections on the intersections of research and policy. Language Sciences, 5. doi.org/10.3389/fpsyg.2014.00358

Curtin, M. (2008). Languages on display: Indexical signs, Identities and the linguistic landscape of Taipei. In E. Shohamy \& D. Gorter (Eds.), Linguistic landscapes: Expanding the scenery (pp. 221-237). Florence, KY: Routledge.

Dagenais, D., Moore, D., Sabatier, C., Lamarre, P., \& Armand, F. (2008). Linguistic landscape and language awareness. In E. Shomamy \& D. Gorter (Eds.), Linguistic landscapes: Expanding the scenery (pp. 253-269). Florence, KY: Routledge.

Dailey, R.M., Giles, H., \& Jansma, L.L. (2005). Language attitudes in an AngloHispanic context: The role of the linguistic landscape. Language \& Communication, 25, 27-38. doi.org/10.1016/j.langcom.2004.04.004

Dressler, R. (2015). Signgeist: Promoting bilingualism through the linguistic landscape of school signage. International Journal of Multilingualism, 12, 128-145. doi.org/10.1080/14790718.2014.912282

Edelman, L. (2014). The presence of minority languages in linguistic landscapes in Amsterdam and Friesland (the Netherlands). International Journal of the Sociology of Language, 2014(228), 7-28. doi.org/10.1515/ijsl-2014-0003

Ewart, G., \& Straw, S. (2001). Literacy instruction in two French immersion classrooms in Western Canada. Language, Culture and Curriculum, 14, 187-199. doi.org/10.1080/07908310108666621

Gade, D.W. (2003). Language, identity, and the scriptoral landscape in Québec and Catalonia. Geographical Review, 93, 429-448.

doi.org/10.1111/j.1931-0846.2003.tb00041.x 
García, O., \& Kleyn, T. (2016). Translanguaging theory in education. In O. García \& T. Kleyn (Eds.), Translanguaging with multilingual students: Learning from classroom moments (pp. 9-33). New York: Routledge.

Genesee, F. (2008). Immersion française et élèves à risques: revue des données de recherche. Canadian Modern Language Review, 63, 689-726.

Gershon, S.A., \& Pantoja, A.D. (2011). Patriotism and language loyalties: Comparing Latino and Anglo attitudes toward English-only legislation. Ethnic and Racial Studies, 34, 1522-1542. doi.org/10.1080/01419870.2010.535549

Gilbert, A. (2010). Territoires francophones?: études géographiques sur la vitalité des communautés francophones du Canada. Quebec: Septentrion.

Goldberg, E., \& Noels, K. (2006). Motivation, ethnic identity, and post-secondary education language choices of graduates of intensive French language programs. Canadian Modern Language Review, 62, 423-447.

Gorter, D. (2013). Linguistic landscapes in a multilingual world. Annual Review of Applied Linguistics, 33, 190-212. doi.org/10.1017/S0267190513000020

Gorter, D. (2018). Linguistic landscapes and trends in the study of schoolscapes. Linguistics and Education, 44, 80-85. doi.org/10.1016/j.linged.2017.10.001

Gorter, D., \& Cenoz, J. (2015). Translanguaging and linguistic landscapes. Linguistic Landscape, 1, 54-74. doi.org/10.1075/ll.1.1-2.04gor

Hermanto, N., Moreno, S., \& Bialystok, E. (2012). Linguistic and metalinguistic outcomes of intense immersion education: How bilingual? International Journal of Bilingual Education and Bilingualism, 15, 131-145. doi.org/10.1080/13670050.2011.652591

Hewitt-Bradshaw, I. (2014). Linguistic landscape as a language learning and literacy resource in Caribbean creole contexts. Caribbean Curriculum, 22, 157-173.

Hornberger, N.H., \& Link, H. (2012). Translanguaging in today's classrooms: A biliteracy lens. Theory Into Practice, 51, 239-247. doi.org/10.1080/00405841.2012.726051

Jørgensen, J.N. (2012). Ideologies and norms in language and education policies in Europe and their relationship with everyday language behaviours. Language, Culture and Curriculum, 25, 57-71. doi.org/10.1080/07908318.2011.653058

Lamarre, P. (2014). Bilingual winks and bilingual wordplay in Montreal's linguistic landscape. International Journal of the Sociology of Language, 2014(228), 131151.

Landry, R., \& Bourhis, R.Y. (1997). Linguistic landscape and ethnolinguistic vitality: An empirical study. Journal of Language and Social Psychology, 16, 23-49. doi.org/10.1177/0261927X970161002

Landry, R., \& Forgues, É. (2007). Official languagex minorities in Canada: an introduction. International Journal of the Sociology of Language, 2007(185), 1-9.

MacSwan, J. (2017). A multilingual perspective on translanguaging. American Educational Research Journal, 54, 167-201. doi.org/10.3102/0002831216683935 
Makropoulos, J. (2010). Students' attitudes to the secondary French immersion curriculum in a Canadian context. Language, Culture and Curriculum, 23, 1-13. doi.org/10.1080/07908310903494525

Manitoba. Education and Training. (2017). English program. www.edu.gov.mb.ca/k12/cur/ english_pr.html

May, S. (2012). Language and minority rights: Ethnicity, nationalism and the politics of language (2nd ed.). New York: Routledge.

Otheguy, R. (2016). Foreward. In O. García \& T. Kleyn (Eds.), Translanguaging with multilingual students: Learning from classroom moments (pp. ix-xii). New York: Routledge.

Otheguy, R., García, O., \& Reid, W. (2015). Clarifying translanguaging and deconstructing named languages: A perspective from linguistics. Applied Linguistics Review, 6, 281-307. doi.org/10.1515/applirev-2015-0014

Pacheco, M.B., \& Miller, M.E. (2016). Making meaning through translanguaging in the literacy classroom. The Reading Teacher, 69, 533-537. doi.org/10.1002/trtr.1390

Pacheco, M.B., \& Smith, B.E. (2015). Across languages, modes, and identities: Bilingual adolescents' multimodal codemeshing in the literacy classroom. Bilingual Research Journal, 38, 292-312. doi.org/10.1080/15235882.2015.1091051

Pennycook, A. (2017). Translanguaging and semiotic assemblages. International Journal of Multilingualism, 14, 269-282. doi.org/10.1080/14790718.2017.1315810

Pennycook, A., \& Otsuji, E. (2014). Metrolingual multitasking and spatial repertoires: 'Pizza mo two minutes coming.' Journal of Sociolinguistics, 18, 161-184. doi.org/10.1111/josl.12079

Pilote, A., \& Magnan, M.-O. (2008). L'éducation dans le cadre de la dualité linguistique canadienne: quels défis pour les communautés en situation minoritaire? Canadian Journal for Social Research, 1, 47-63. www.ciim.ca/img/boutiquePDF/ canadianjournalforsocialresearch-revuecanadiennederecherchesociale-vol1-no1-2008-zr5p4. pdf

Plessis, T. (2011). Language visibility and language removal: A South African case study in linguistic landscape change. Communicatio, 37, 194-224. doi.org/10.1080/02500167.2011.604170

Poza, L. (2017). Translanguaging: Definitions, implications, and further needs in burgeoning inquiry. Berkeley Review of Education, 6. doi.org/10.5070/B86110060

Przymus, S.D., \& Kohler, A.T. (2018). SIGNS: Uncovering the mechanisms by which messages in the linguistic landscape influence language/race ideologies and educational opportunities. Linguistics and Education, 44, 58-68. doi.org/10.1016/j.linged.2017.10.002

Rowland, L. (2013). The pedagogical benefits of a linguistic landscape project in Japan. International Journal of Bilingual Education and Bilingualism, 16, 494505. doi.org/10.1080/13670050.2012.708319 
Roy, S. (2010). Not truly, not entirely ... Pas comme les Francophones. Canadian Journal of Education, 33, 541-563.

Saindon, J., Landry, R., \& Boutouchent, F. (2011). Anglophones majoritaires et français langue seconde au Canada: effets complémentaires de la scolarisation et de l'environnement social. Canadian Journal of Applied Linguistics, 14, 106-140.

Sayer, P. (2010). Using the linguistic landscape as a pedagogical resource. ELT Journal, 64, 143-154. doi.org/10.1093/elt/ccp051

Sayer, P. (2013). Translanguaging, TexMex, and bilingual pedagogy: Emergent bilinguals learning through the vernacular. TESOL Quarterly, 47, 63-88. doi.org/10.1002/tesq.53

Shohamy, E. (2012). Language policy: Hidden agendas and new approaches. Hoboken: Taylor and Francis.

Smith, B., Pacheco, M., \& de Almeida, C. (2017). Multimodal codemeshing: Bilingual adolescents' processes composing across modes and languages. Journal of Second Language Writing, 36, 6-22. doi.org/10.1016/j.jslw.2017.04.001

Swain, M., \& Lapkin, S. (2008). Beginning French immersion at Grade 8. Orbit [thematic issue: The best of our history], 37(2/3), 56-59. (Reprinted from Orbit, 8, 10-13 [1977]) archive.org/details/orbit2008v37i23oise/page/56

Szabó, T.P. (2015). The management of diversity in schoolscapes: An analysis of Hungarian practices. Apples - Journal of Applied Language Studies, 9, 23-51. doi.org/10.17011/apples/2015090102

Velasco, P., \& García, O. (2014). Translanguaging and the writing of bilingual learners. Bilingual Research Journal, 37, 6-23. doi.org/10.1080/15235882.2014.893270

Williams, C. (1996). Secondary education: Teaching in the bilingual situation. In C. Williams, G. Lewis, \& C. Baker (Eds.), The language policy: Taking stock: Interpreting and appraising Gwynedd's language policy in education (pp. 39-78). Llangefni, UK: Canolfan Astudiaethau Iaith (CAI) Language Studies Centre. 